\title{
Metallic Object
}

National Cancer Institute

\section{Source}

National Cancer Institute. Metallic Object. NCI Thesaurus. Code C83000.

An object composed of, or containing metal. 